\title{
AB-Türkiye İlişkileri Bağlamında Toplumsal Cinsiyet Politikaları AB İlerleme Raporları Perspektifinden Bir Değerlendirme
}

\author{
Gender Policies in the Context of EU-Turkey Relations \\ An Evaluation from the Perspective of the EU Progress Reports
}

Prof. Dr. Ali Ayata ${ }^{1}$ - Hande Saadet Takkaç ${ }^{2}$

Başvuru Tarihi: 16.11 .2019

Kabul Tarihi: 16.06 .2020

Makale Türü: Derleme

Öz

Toplumsal cinsiyet, bireylerin biyolojik cinsiyetinin çok daha ötesine geçerek bireyin cinsiyetine toplumsal ve kültürel özellikler yüklenen anlamlar ile ortaya çıkan farklı bir kavramdır. Toplumsal cinsiyet konusunda yürütülen çalışmalar sadece kadınlarla ilgili olmayıp, cinsel kimliklerin hesaba katılarak farklı cinsel eğilimlerin ve bunlara yönelik ayrımcı tutumların dikkate alınmasını zorunlu kılar. Bunun yanında ilgili gurubun hakların bilmesi ve kullanabilmesi, toplumun diğer üyeleri ile uyum içinde yaşayabilmesi ve diğerleri gibi etkin bir rol alabilmesi ile doğrudan bağlantılıdır. Dünya tarihinde bireylerin sahip olduğu en eski farklıliklardan birisi olan cinsiyet konusu, insan haklarının benimsenmesi ile eşitsizlik olmaktan çıkarılmaya çalışılmıştır. İnsan hakları konusundaki yükselen duyarlılık, bireylerin üzerlerinde barındırdıkları farklılıkların bir önemi olmaksızın eşit oldukları anlayışını pekiştirmiştir. Toplumsal cinsiyet olgusu, derinliği sabit olmamakla birlikte dünyanın pek çok ülke ve toplumunda yaşanan bir eşitsizlik sorundur. Türkiye, AB ile ilişkilerinin önemli bir ayă̆ını oluşturan toplumsal cinsiyet konusunda uzun yıllar boyunca ikircikli bir tutum izlemişse de, özellikle son yillarda hem kendi iç motivasyonu hem de AB üyelik müzakere süreçlerinin zorlamalarıla ilerlemeler kaydetmiştir. 1998 yılından itibaren AB Komisyonu tarafindan ortaya konulan Türkiye İlerleme Raporlarında bu alandaki gelişmeler ve iyileşmeler yanında yetersizlik ve eksiklikler sürekli dile getirilmiştir. Gelinen noktada, toplumsal cinsiyet konusu Türkiye'nin $A B$ ile ilişkilerinde henüz tam anlamıyla çözüm üretemediği ve kısa vadede çözüm üretilmesi de mümkün olmayacak sorun alanları arasında yer almaktadır. Bu çalışmada öncelikle toplumsal cinsiyet konusu kavramsal çerçevede incelenmiş, daha sonra da toplumsal cinsiyet konusunun $A B$ bünyesindeki gelişimi ele alınmıştır. AB İlerleme Raporları yıllar itibarı ile ayrı ayrı incelenerek, toplumsal cinsiyet konusunda Türkiye'nin mevzuat ve uygulama boyutunda yaşadiğı gelişmeler değerlendirilmiştir.

Anahtar Kelimeler: Toplumsal Cinsiyet, Kadın Erkek Eşitliği, AB-Türkiye İlişkileri

\footnotetext{
${ }^{1}$ Karamanoğlu Mehmetbey Üniversitesi İİBF Siyaset Bilimi ve Uluslararası İlişkiler Bölümü, aayata@kmu.edu.tr, ORCID: 0000-0002-58906425

${ }^{2}$ Karamanoğlu Mehmetbey Üniversitesi Sosyal Bilimler Enstitüsü, hande_takkac@hotmail.com, ORCID: 0000-0002-1928-6243
} 


\section{Abstract}

Gender is a distinct concept that goes beyond the biological sex of individuals and emerges with the meanings that give social and cultural characteristics to the sex of the individual. Gender studies require not only the studies about women, but also the consideration of different sexual orientations and sexual identities, and discriminatory attitudes towards them. In addition, the fact that individuals take an active role in society is closely related to the fact that they live in harmony with society, know and exercise their rights. Gender, which is one of the world's oldest differences among individuals, has been tried to be removed from being an inequality thanks to the adoption of human rights. The increased sensitivity about human rights reinforced the understanding that the individuals are equal regardless of the differences among them. Gender phenomenon, although its depth is not constant, is an inequality problem in many countries and societies of the world. Although for many years Turkey have had an ambivalent attitude about the issue of gender which constitutes an important pillar of relations between Turkey and the EU, especially in recent years it has made progress by the enforcement of both its internal motivation and EU membership negotiation process. Not only the developments and improvements but also the deficiencies and shortcomings in this area have been constantly expressed in EU Commission's Turkey Progress Reports since 1998. At this point, the issue of gender is among the problem areas that Turkey literally could not find solution in its relations with EU and it is not possible to find a solution in the short run. In this study, first of all, the issue of gender has been conceptually examined and then the development of the gender issue within the EU has been discussed. The developments about gender in Turkey in terms of legislation and practices have been evaluated by examining the EU Progress Reports separately in annual basis.

Keywords: Gender, Gender Equality, EU-Turkey Relations

\section{Giriş}

Uzun yıllar süregelen savaşlar sonrasında barış ve demokrasinin erdeminin anlaşılması ve özellikle insan hakları konusundaki yükselen duyarlılık, bireylerin üzerlerinde barındırdıkları farklılıkların bir önemi olmaksızın eşit oldukları anlayışını pekiştirmiştir. Bireyler arasındaki en eski ve belki de tarih boyunca her toplumun az ya da çok tartışma konusu olan farklılık, cinsiyet meselesidir. Kadınların erkekler karşısında eşitsizlikler içinde oldukları inancı, temel haklar konusundaki eşitsizliklerin ortadan kaldırılması ve kendilerinin bu haklardan yararlanmalarını istemelerine yol açmıştır. Başlangıçta bu hak arayışı, sadece kadınların kendi özel mücadelesi şeklinde görülmüştür. Ancak her hangi bir ülkede toplumun ve dolayısıyla beşeri sermayenin aşağı yukarı yarısını oluşturan kadınların katkısı ve katılımı olmaksızın demokratik bir toplumun kurulamayacağı anlaşılmıştır. Kadınların katkısının alınamadığı bir ortamda ekonomik, sosyal ve kültürel boyutları da kapsayıcı sürdürülebilir kalkınma hedeflerine ulaşılmasının mümkün olmadığının anlaşılması, söz konusu hak arayışları sürecinin yeni destekçisi olarak devletleri öne çıkarmıştır. Bu noktadan itibaren kadın-erkek eşitliği konusu toplumsal bir mesele olarak görülmeye başlanmıştır. Ancak bu kez, söz konusu sorunda temel belirleyicilerin toplumsal önyargıların ya da kalıplaşmış yargıların olduğu saptanmıştır. Böylece sorun, bireylerin salt biyolojik farklılıklarından kaynaklanan bir boyuttan çok daha öteye 
taşınmış ve toplumsal cinsiyet sorunsalı olarak ortaya çıkmıştır. Bu çerçevede ilk etapta ulusal ölçekte toplumsal cinsiyet eşitsizliğinin ortadan kaldırılmasına yönelik çabalar ve düzenlemeler yapılmıştır. Ancak yeterli bir ilerleme sağlanamaması ya da ilerlemenin çok sınırlı alanlarda başarılı olmasından ötürü konuyu uluslararası ölçekte çözüm arayışlarına muhatap kılmıştır. Birleşmiş Milletler, Dünya Bankası gibi kuruluşlar aracılığıyla toplumsal cinsiyet eşitsizliğinin kalkınma hedefleri açısından önemli bir engel oluşturduğu gerekçesiyle özellikle gelişmekte olan ülkelere bir şekliyle zorunlu politika transferi biçimine dönüşmüştür.

Avrupa Birliği de benzer bir yaklaşımla toplumsal cinsiyet eşitsizliklerinin hem bireylerin gelişimi için hem de ülkelerin refah seviyelerini yükseltebilmelerinin önemli engellerinden birisi olduğunu düşünmüştür. İlk aşamada kadın-erkek ücret eşitliği üzerinden hareket edilse de, süreç ekonomik topluluktan siyasal ve sosyal bütünleşmeye doğru evirildikçe toplumsal cinsiyet eşitliğine yönelik politikalar, hem üye ülkelere hem de genişleme ile birlikte aday ülkelere de benimsetilmeye çalışılmıştır. Türkiye, AB ile ilişkilerinin önemli bir ayağını oluşturan toplumsal cinsiyet konusunda uzun yıllar boyunca biraz ikircikli bir tutum izlemişse de, özellikle son yıllarda hem kendi iç motivasyonu hem de AB üyelik müzakere süreçlerinin zorlamalarıla ilerlemeler kaydetmiştir. Türkiye açısından gelinen nokta, henüz yeterli ve tatmin edici kabul edilmemektedir. Ancak belirtilmelidir ki bu eksiklik, yapılan düzenlemelerin yetersizliğinden daha çok toplumsal cinsiyet sorunsalının ülkedeki bütün dinamiklerin ilgi gösterdiği ve duyarlı olduğu bir seviyeye erişememiş olmasından kaynaklanmaktadır. $\mathrm{Bu}$ çalışmada öncelikle toplumsal cinsiyet konusu kavramsal çerçevede incelenmiş, daha sonra da toplumsal cinsiyet konusunun AB bünyesindeki gelişimi ele alınmıştır. Özellikle toplumsal cinsiyet konusunun ana akımlaştırılmasına yönelik atılan adımlar değerlendirilmiştir. Üçüncü ve son aşamada ise toplumsal cinsiyet politikaları perspektifinden Türkiye-AB ilişkilerindeki yansımaları ortaya konulmaya çalışılmıştır. Bu çerçevede hareket noktasını, 1998-2018 yıllarını kapsayan AB İlerleme Raporları oluşturmuştur. Bu süreçteki ilerleme raporları yıllar itibarı ile ayrı ayrı incelenerek, belgesel tarama yöntemi uyarınca toplumsal cinsiyet konusunda Türkiye'nin mevzuat ve uygulama boyutunda yaşadığı gelişmeler değerlendirilmiştir.

\section{Cinsiyet-Toplumsal Cinsiyet Kavramları ve Ayrımı}

Cinsiyet sözcügü İngilizce’deki “sex” sözcüğünün karşıllğı olarak bireyin kadın veya erkek olmanın biyolojik boyutunu temsil eder. Aslında cinsiyet kavramı, bireyin biyolojik cinsiyetine bağlı olarak belirlenmiş demografik kategoriye vurgu yapar. Örneğin bağımsız değişken olarak ele alındığı zaman cinsiyet terimiyle, bireye ait genetik ve kromozom birleşimi (erkek için xy, kadın için xx), iç ve dış üreme organları vurgulanmaktadır. Ayrıca bir cinsiyetin diğerinden önemli derecede farklılaşmasına neden olan ikincil nitelikteki cinsel karakteristik örneği olarak erkek vücudunun kadına kıyasla daha kıllı ve kaslı olması gibi bireyin biyolojik cinsiyetine referans vardır. Dolayısıyla kimlik kartlarındaki cinsiyet bölümü ile ortaya konulan bireyin biyolojik cinsiyetidir (Pehlivan, 2017, s.498). Toplumsal cinsiyet kavramı ise, biyolojik cinsiyetten farklı şekilde, erkek ve kadının sosyo-kültürel açıdan tanımlanması, toplumun söz konusu iki türün birbirinden ayırt etme biçimi ve onlara verilen toplumsal rollerin betimlenmesi için kullanılır. İngilizcedeki "gender” sözcüğünün karşılığı olarak kabul edilir. Nitekim Ann Oakley, bu sözcügü ilk kez kullanan kişi olarak erkek ve kadın arasındaki 
toplumsal bölünmüşlüğe vurgu yapar. Böylelikle toplumsal cinsiyetle, kadın ve erkek arasındaki farklılıkların toplumsal boyutu işaret edilir (Ersoy, 2009, s.210). Kavramın önemi, kadın ve erkek arasındaki güç ilişkilerinin anlaşılması, eşitsizliklerin sorgulanması için kullanışlı bir araç olarak görülmesi sonrasında artmıştır. 1970’li yıllar ile birlikte başlayan toplumsal cinsiyet çalışmaları üç aşamalı bir süreçten geçmiştir. İlkinde, kadın-erkek cinsiyet farklılıklarının öne çıkarıldığı aşamadır. Bu aşamadaki araştırmacılar, söz konusu farklılıkların bireylerin biyolojik özellikleri kaynaklı olduğu konusunda uzlaşı içindedirler. İkinci aşama, öğrenilen cinsiyet rolleri ve toplumsallaşma vurgusunun önem kazandığı aşama olmuştur. Bu aşamada toplumsal cinsiyetin, kadın bireye indirgenmeksizin, özgül toplumsal düzenlemelerin bir ürünü olduğu benimsenmiştir. Üçüncü aşamada ise, toplumsal cinsiyetin sınıflı ya da ataerkil bütün toplumsal sistemlerde temel bir rol oynadığı belirlenmiştir (Ecevit, 2011, s.4). Başka bir anlatımla, toplumsal cinsiyet, ücretli çalışmadan aile, politika, gündelik yaşama kadar, ekonomik kalkınmadan hukuk, eğitim, teknoloji ve daha çok sayıda alanda inceleme sürecine dâhil edilmiştir.

Kavram olarak cinsiyet ile biyolojik farklılaşma ötesinde erkek ve kadına dair toplumsal bir tanımlama da yapılmış olmaktadır. Böylece kadın ve erkek için toplumdaki konum ve davranışları da belirlenmektedir. Buradan bakınca cinsiyet kavramını toplum oluşturmaktadır ve dolayısıyla da toplumdan topluma ya da zaman içinde değişkenlik gösterebilmektedir (Pehlivan, 2017, s.498). Birey, dişi ya da erkek cinsiyeti ile doğmaktadır, ancak yetiştiriliş sürecinde ve sosyalleşme sayesinde içinde yer aldıkları toplumun cinsiyetlere özgü beklediği roller doğrultusunda "kız" ya da "erkek" çocuk olmayı öğrenir. Kız ve erkek çocuklar, çeşitli nesneleri, etkinlikleri, oyun ve meslekleri ve kişilik özelliklerini bile kendileri açısından "uygun" ya da "uygun olmayan" şeklinde ayırt eder hale gelirler. Cinsiyet kavramı bu noktadan itibaren basit bir dişil-eril ayrımının çok daha ötesine geçerek yeni ve farklı anlamlar kazanmaya başlar. Erkek ve kadın için yüklenen bu yeni anlamlar ile birey, sosyal yaşamda benimsenen ve kamuoyu algısında yer ediniş roller içerinde sıkışıp kalmaktadır (Saraç, 2013, s.27). Buradan hareketle de biyolojik cinsiyetin yerini, statü belirleyicilik özelliği taşıyan toplumsal cinsiyet anlayışına bıraktığı görülmektedir. Bundan sonra kadın ve erkek sadece toplumsal paradigma tarafından onlar için belirlenmiş eylem ve davranışları uygulamakla yükümlü hale gelmişlerdir.

\section{Toplumsal Cinsiyet Rollerinin Gelişimini Etkileyen Faktörler}

Toplumsal cinsiyet rollerinin öğrenildiği ya da öğretildiği ilk yer, en küçük toplumsal birim olan aile kabul edilmektedir. Kültür farklılıklarına bağlı olarak değişiklik gösteren aile yapısı, toplumun toplumsal cinsiyet anlayışını da yansıtan bir gösterge gibidir. Örneğin ataerkil bir ailede erkek yüceltilirken, anaerkil bir aile için kadın daha önde ve üstte kabul görür. Toplumun erkek veya kadına yönelik beklentisi aile kurumu tarafından çocuğun doğumu ile birlikte bazen bilinçli şekilde bazen de bilinçsiz olarak çocuğa empoze edilmeye başlanır. Çocuk, erkek ya da kadın için uygun bulunan davranış kalıpları doğrultusunda biçimlendirilir (Aslan, 2015, s.365; Ateş, 2018, s.9). Aile, farklı roller doğrultusunda birbirini etkileyen bireylerden oluşmaktadır ve üyelerinin yaşam tatmin düzeyinin yükseltilmesinde belki de en önemli kurum olarak kabul edilir. Aile içinde temel ekonomik ve sosyal kararın alınış yöntemi ile eşlerin aralarında yaptıkları faaliyet paylaşımı, duygu ve düşünceleri, aile bireylerinin birbirlerinin davranışları 
üzerindeki etkileme düzeyleri ortaya konulur. Ailedeki bütün ekonomik, sosyal veya fizikî konulara ilişkin sorumluluk dağılımı vardır (Şafak, 1989, s.37; Günay ve Bener, 2011, s.159). Şöyle ki geleneksel olarak ailedeki görev ve sorumluluk dağılımında cinsiyete göre hareket edilir. Örneğin erkekler tamir, bağ-bahçe işlerini yapmakla görevli ve sorumlu kılınırken, kadınlar ise yemek yapmak, temizlik yapmak ve bulaşık yıkamak gibi görev ve sorumluluklar ile yükümlüdürler.

Okul ve eğitim sistemi, toplumsal değerlerin bireylere aşılanması işlevini yerine getirmektedir. Ama aynı zamanda bireye geleceğe yönelik bir meslek edindirmek görevini de yerine getirmektedir. Ancak sadece bu görev ve yükümlülüklerle kalmayıp aynı zaman da ailede başlamış olan toplumsal cinsiyet öğrenimi ya da öğretimi işini de kaldığı yerden devam ettiren ve pekiştiren bir rol üstlenmiştir. Burada çocuklara cinsiyet kaynaklı roller, beklentiler, davranış kalıpları, anlayış ve yükümlülükler örtük ya da açık olarak benimsetilmektedir. Okullarda müfredat ve ders materyalleri yani kitaplar ve diğer gereçler ve öğretim elemanlarının da toplumsal cinsiyet rollerinin çocuklara aktarılmasında kullanılan önemli araçlar arasındadır. Öğretim elemanlarının davranışları ve ders kitapları ve diğer gereçlerdeki toplumsal cinsiyet rollerine ilişkin metin, resim ve görseller aracılığıla çocuklar kendilerinden gelecekte beklenmekte olan toplumsal cinsiyet rollerine hazırlanmaktadırlar (Ateş, 2018, s.10-11). Örneğin öğretmenlerin çocuklara çoğunlukla farkında bile olmaksızın cinsiyetlerine göre farklı davranmaktadırlar.

Yaşıtlar, yaşadıkları mahallelerde ve okullarında aynı cinsteki arkadaşlarına erkeksi ya da kadınsı rolleri öğretmektedirler. Özellikle ergenlik döneminde arkadaş çevresinin onaylaması veya onaylamaması, çocukların gösterebilecekleri cinsel davranış ve tutumlar üzerinde önemli etkiye sahip olmaktadır. Aynı yaş grubundaki çocuklar, kendi cinsiyetleriyle uyumlu davranış içinde olanları onaylarken uygun davranış içinde olmayanları da onaylamamaktadırlar. Böylece cinsiyet rollerinin gelişimine ve yerleşmesine katkı yapmaktadırlar. Literatürde büyük kardeşin küçük kardeş açısından cinsiyetlerine uygun bir rol model olduğuna yönelik çok sayıdaki araştırmaya sahiptir. Çocuğun aynı cinsten olan büyük kardeşinin davranışları, onun cinsiyetine ilişkin davranışlar edinme sürecinde destek olmaktadır. Kardeşler arasında gerçekleşen oyun ve çeşitli faaliyetler de toplumsal cinsiyet rolleri ile güçlü düzeyde ilişkili bulunmuştur. Toplumsal cinsiyetin çocuklara öğretilmeye başlandığı ilk aşama aile kabul edilmekteyse de, özellikle günümüzde başta televizyon olmak üzere diğer medya araçlarının da çocuklar çok küçük yaşlardayken etkili bir toplumsal cinsiyet rollerinin öğrenildiği/öğretildiği alanlardan birisi haline gelmiştir. Günümüzde çocuklar çok erken yaşlardan itibaren televizyon bağımlısı bireyler haline gelmişlerdir. Medya sektörü de kendileri açısından önemli bir kazanç fırsatı olarak gördükleri bu alana ciddi yatırımlar yapmaktan geri kalmamışlardır. Çocuklara yönelik programlar, çizgi film ve diğer yapımları üretmeye devam etmektedirler. Çocuklara yönelik bu ürünler ile de toplumun değerleri, kuralları, gelenekleri ve davranış kalıpları öğretilmektedir. Bu programlar ya da diğer ürünler aracılığıyla çocuklar için önemli rol modeller ortaya çıkarılmaktadır. Bireyler, toplumsal yaşama yeni girmiş olan davranışlardan hangisinin ya da hangilerinin erkek için hangisi ya da hangilerinin kadın için uygun olduğunu çoğunlukla filmler, çizgi romanlar veya reklamlar aracılığıyla öğrenirler (Çifçi, 2018, s.26). Öte 
yandan medyanın bir toplumsal yargılama mekanizması şeklinde rol üstlenmeye çalıştığı da görülmektedir. Şöyle ki toplumsal değerlerden hangilerinin doğru ve uygun, hangilerinin ise hatalı olduğu, adeta medya tarafından yapılan çeşitli yayın ya da aktiviteler ile kararlaştırılmaktadır. Medyada yer alan kadın ve erkek sembollerin tek tipleştirilmiş olması ve klişe bir şekilde sunuluşu, bir anlamda toplumdaki yerleşik eğilimlerin desteklenmesi demektir (Saka, 2018, s.28).

\section{Avrupa Birliği'nde Toplumsal Cinsiyet Politikalarının Tarihsel Gelişimi}

Toplumsal cinsiyet eşitliği, Avrupa Birliği (AB)'nin üzerinde kurulduğu ortak değerle arasındadır. Bu nedenle de ilk aşamadan bu yana AB'nin en önemli politika alanlarından birisi olmuştur. Ancak bu sürecin başlangıcında, Ortak Pazar temel hedefinin benimsendiği Avrupa Ekonomik Topluluğu'nun toplumsal cinsiyet konusuna bakışı da bu boyutta gerçekleşmiştir. Yani Topluluk içinde emek, sermaye, hizmet ve malların serbest dolaşımı bağlamında kadınerkek eşitliği politikalarının daha çok işgücü piyasasında fırsat eşitliği motivasyonuyla uygulamaya geçirildiği görülmektedir (Yılmaz, 2009, s.79; Göçmener, 2008, s.64). Kadın-erkek eşitliği şeklinde daha sınırlı bir boyutuyla AB sürecinin ilk kez kendi mevzuatına girişi 1957 yılındaki Roma Antlaşması ile olmuştur. Bu antlaşmanın 119. Maddesi AB açısından bir temel teşkil ederken, rekabet ve işgücü temeli üzerine kurulması nedeniyle Roma Antlaşması'nın üye ülkelerdeki etkisi noktasında ve toplumsal cinsiyet eşitliği bakımından etkisi ciddi tartışmalara yol açmıştır (Tatlıer Baş, 2011, s.51-52; Gülel, 2012, s.19). AB’nin toplumsal cinsiyet politikaları, üç temel anlayışa dayandırılmaktadır. Kronolojik sırasıyla bu yaklaşımları; eşit ücret ve eşit davranış politikaları, pozitif ayrımcılık ya da olumlu eylem yaklaşımı ve toplumsal cinsiyet politikalarının temel düzenlemelere yerleştirilmesi anlamına gelen ana akımlaştırma yaklaşımı şeklinde sıralanabilir.

Birincisi, "eşit ücret ve eşit davranış politikaları" şeklinde ifade edilebilecek daha çok yasalar nezdinde eşitlik anlamına gelen liberal politikaların bir sonucu olmuştur. Bu politikaların pratikteki karşılığı, kamusal alanlarda kadın ve erkeğin eşit hak ve fırsatlara sahip olması biçiminde olmaktadır. Kanuna uygun araçlardan yararlanıldığı politikalar olarak da ifade edilen bu süre. AB'de fırsat eşitliği politikaları şeklinde literatürde kendisine yer bulmuştur (Yılmaz, 2009, s.79). "Eşit işe eşit ücret ilkesi” ile çalışanlarla ilgili olarak kadın ve erkek eşitliğinin sağlanmak hedeflenmektedir. Bu maddeye göre; "Her üye devlet aynı is için kadın isçilerle erkek isçiler arasındaki ücret eşitliği ilkesinin uygulanmasını ilk devre süresinde sağlar ve bunu daha sonra devam ettirir. Cinsiyet farkı gözetmeden kurulan ücret eşitliği;

- Parça başına ödenen ücretin aynı ölçü birimi üzerinden hesaplanmasını,

- Zaman esasına göre ödenen ücretin aynı isler için eşit olmasını kapsar.

$\mathrm{Bu}$ maddede ücret konusunda cinsiyete dayalı olarak bir ayrım yapılamayacağına ilişkin kesin bir hüküm yer almıştır. Fakat bu maddede kadınların çalışma yaşamında karşılaşacakları dolaylı veya doğrudan ayrımcılıkla ilgili olarak onları koruyucu bir düzenleme bulunmamaktadır. Eşit Muamele politikalarının uygulandığı dönem eşit muamele yönergesiyle (1976) birlikte AB'de de sosyal boyutun ikinci gelişme süreci olan 1970'lerin ortasından 1980'lere kadardır. Yeni siyasi ve sosyal hareketlerin artması, sosyal liberal yönetimler ve istihdamda yükseliş ve 
Topluluğun, Birleşik Krallık, İrlanda ve Danimarka'yı da içine alarak büyümesi bu dönemin en önemli özellikleridir. Bu dönemde çalışma politikasında iyileştirmeye gidilmiş, çalışanların sağlığı ve güvenliği konusunda düzenlemeler yapılmıştır (Ayata, 2009, s.36).

İkinci yaklaşımla aslında ikinci dalga feminizm ile beraber ortaya çıkan toplumda dezavantajlı durumdaki kadınların, kamusal alanlarda erkeklere yetişebilmeleri açısından bazı ayrıcalıklar elde etmeleri yoluyla söz konusu dezavantajlı konumlarından uzaklaşmaları ya da erkekler ile eşit başlangıç şansı yakalayabilmeleri için üretilen çeşitli önlemler kastedilmektedir. Başka bir anlatımla "pozitif ayrımcılık" ya da "olumlu eylem" olarak da tanımlanan bu yaklaşım, daha çok kadınların penceresinden bir bakış açısı anlamına da gelmektedir (Yılmaz, 2009, s.79). Olumlu eylem yaklaşımının ilk izlerine 1960’lı yıllarda siyah ırk ayrımcılığını yaygın olduğu dönemde geri kalmış kesimler için eşit işlem şansı sağlayıcı özel tedbir için kullanılması sürecinde rastlanır. Başlangıçta "yapıcı eylem” terimini kullanan ABD Başkanı Kennedy, ırk ayrımcılığının olumsuzluklarını ortadan kaldırmak açısından özellikle istihdam alanındaki çeşitli zorlayıcı tedbirlerin de yer aldığı bazı düzenlemelerde "olumlu ayrımcılık" kavramını kullanmıştır (Öztan, 2004, s.207).

$\mathrm{AB}, 1980$ 'lerden itibaren dar kapsamlı, kadın-erkek arasındaki eşitsizliği gidermeyen eşit davranış yaklaşımından, özel önlemleri içeren olumlu eylem yaklaşımına doğru ilerlemiştir. Genel olarak bakıldığı zaman olumlu eylem, azınlıkların ya da sosyal açıdan avantajsız konumda bulunan grupların karşı karşıya kaldıkları ayrımcılığa karşı birtakım özel önlemlerle konumlarını düzeltmeyi amaçlayan politikalardır. Ayrımcılığa uğrayan gruplar ırk ve cinsiyet temelinde önemli yer tutmaktadır. Cinsiyet derken söz konusu olan hiç kuşkusuz kadınların uğradıkları ayrımcılıktır. Olumlu eylem geleneksel tutum alışlara karşı ayrımcılığa uğrayan kitleye eşit fırsatlar sağlamayı amaçlamaktadır. Olumlu eylem politikalarına kadınlar açısından yaklaşırsak bazı özel eylemlerin uyarlanmasıyla ataerkil toplumda eşit olmayan başlangıç durumlarının üstesinden gelmeye yarayan bir araçtır denebilir (Yücel, 2012, s.114). Kadınların tüm iş alanlarında ve her kademede yer alması için eşit şartlar sağlanması gerektiğini savunan bir politika aracıdır.

Eşit davranış politikasının soyut bir hak eşitliği olarak yorumlandığına ve sınırlarının böyle çizildiğine dikkat çekilmektedir. Zaman içinde soyut eşitliğin durum eşitliğini sağlamaktan uzak olduğu iyice açığa çıkınca, olumlu eylem önlemleri tartışılmaya başlanmıştır. Olumlu eylem önlemleri, kadınlarla erkeklere eşit muamelenin gerçekleşmesi için kadınların (işgücü piyasasındaki) “özel” durumlarının göz önüne alınmasını kabul edilebilir hale getirmektedir. Aslında bu önlemlerle amaçlanan ataerkil örüntülere sahip erkeklere yönelik alanlarda kadınların rekabet edebilmeleridir. AB'de de pozitif ayrımcılık politikaları daha çok çalışma yaşamına yöneliktir ve işe eşit olmayan konumda başlayan kadınlara bu eşit olmayan konumlarını gidermek amacıyla sağlanan bir ayrıcalıktır (Yılmaz, 2009, s.86). AB'nin olumlu eylem politikasında kadın istihdamını artırmakla doğru orantılı olarak çalışma yaşamına katılımı sağlayan mesleki eğitime daha çok ağırlık verilmektedir. Kopenhag Kriteleri, Avrupa Birliği'ne üye ülkeleri eşit haklara saygı gösterip topraklarında her türlü ayrımcılığa karşı (kadınlara karşı ayrımcılık da dâhil) savaşmakla yükümlüdürler. Örneğin bazı çevreler sadece 
“öncelikli muamele önlemlerini, yani kotaları olumlu eylem önlemleri olarak görmekteler. Ayrıca özellikle çalışma yaşamında cinsiyet ayrımcılığını önlemek amacıyla "koruma tedbirleri” ya da "fırsat eşitliği politikaları" da uygulanmaktadır. Koruma tedbirleri çoğunlukla hamilelik ve annelik ile ilgili koruyucu yasal çerçeveyi oluşturmaktadır (Yılmaz, 2009, s.90). AB'nde pozitif ayrımcılık yaklaşımının uygulama alanı bulduğu düzenlemeler; 76/207/EEC sayılı yönerge, 13 Kasım 1984 tarihli Konseyin Kadınlar için Olumlu Eylemin Geliştirilmesi Tavsiye Kararı, 1980 ve 1990’larda çıkarılmış olan dört tane Eylem Planı kabul edilmektedir (Tatlıer Baş, 2011, s.55-59).

Üçüncü yaklaşım ise, 1990'lı yıllarla birlikte gelişen bir kavram olan toplumsal cinsiyet eşitliğinin anaakımlaştırılması, toplumsal cinsiyet vurgusunun önem kazandığı, kadın ve erkek farklılıklarının üstünde yoğunlaşıldığı ve toplumsal cinsiyet konusunun temel politikalara yerleştirilme eğiliminin yaygınlık kazandığ 1 bir dönemdir. $\mathrm{Bu}$ politikaların ana akımlaştırılmasında 1997 yılındaki AB düzeyinde istihdam açısından saptanan hedefler ve 2000 sonrasının uygulamaya başlayan istihdam stratejisinin büyük önemi vardır. AB'nin 1997 yılındaki Amsterdam Antlaşması ile sosyal politikalarda daha etkin bir rol oynamaya başladığı görülür. Aslında bu antlaşmayla eşitlik politikalarında ana akımlaştırma yaklaşımı başlatılmıştır. 2000 yılında benimsenen “Cinsiyet Eşitliği İçin Çerçeve Strateji” ile AB'nin cinsiyet eşitliği rolünde bir genişleme dikkat çekmektedir (Koray, 2011, s.21). Bu strateji ile AB, ekonomik yaşam, siyasal katılım ve temsil, sosyal hakların kullanılması, sivil yaşam ve kadın ve erkeklerin rolleri gibi beş temel konuda cinsiyet eşitliğini sağlamak adına teşvik eden bir rol üstlenmiştir. Ana akım politikası yahut anaakımlaştırma, cinsiyete dayalı ayrımcılıklarla ortaya çıkan engellerin farkında olarak cinsiyet eşitsizliklerin toplumsal kalkınma ve demokratikleşmeye engel olduğu düşüncesi ile ülke politikalarının oluşturma ve uygulama aşamalarında yapılan her türlü plan ve programlarda cinsiyet farklılığını dikkate alınması anlamına gelmektedir (Eray, 2015, s.121). Bu süreçte AB'nin toplumsal cinsiyet politikalarının temel düzenlemelerde yer almasını sağlama noktasında bu ülkelerde faaliyet gösteren feminist grupların da oldukça etkili oldukları bilinmektedir.

\section{AB'ye Üyelik Sürecinde Türkiye'de Toplumsal Cinsiyet Politikaları}

1999 yılında gerçekleşen Helsinki Zirvesi ile birlikte Türkiye aday ülke statüsünü elde etmiştir. $\mathrm{AB}$, zirvede aldığı karar doğrultusunda Türkiye'nin $\mathrm{AB}$ müktesebatına uyumunu sağlamak amacıyla Katılım Ortaklığı Belgesi'nin hazırlanmasına da karar vermiştir. Türkiye de 2001 yılında Bakanlar Kurulu tarafından onaylanan Ulusal Program ile söz konusu müktesebata uyum konusunda atılacak adımlar için bir yol haritası belirlemiştir. AB 2001 Katılım Ortaklığı belgesinin talepleri arasında kısa vadede kadın - erkek eşitliğine ve cinsiyet ayrımcılığına dair bir talep görmek mümkün değildir. Fakat belgenin orta vade beklentileri arasında kadınlara karşı ayrımcılık uygulamalarının ve cinsiyet, ırk ve etnik köken, din ve inanç, sakatlık, yaş ve cinsi eğilim nedenlerine dayalı tüm ayrımcılık uygulamalarının ortadan kaldırılması bulunmaktadır. Ayrıca kadın - erkek arasında fırsat eşitliğinin sağlanması adına iş hukukunda cinsiyetler arası eşitlik ve iş koşullarında eşit muamele talepleri vardır. Türkiye'de toplumsal cinsiyet konusundaki yasal değişim sürecinde; uluslararası örgütler, kadın sivil toplum kuruluşları ve kamu kurumlarının üç önemli aktör olarak öne çıktığı görülmektedir. Birleşmiş 
Milletler ve Avrupa Birliği bu uluslararası örgütlerde başı çekmektedir. Uluslararası örgütlerin toplumsal cinsiyet politikalarının anaakımlaştırılması sürecinde 1982 Anayasası'nın 90. Maddesinin belirleyiciliği vardır. Parlamento onayından geçen bir uluslararası sözleşmenin kanun üstünde bir norm gücü kazanıyor olması nedeniyle bu uluslararası örgütlerle yapılan anlaşmaların yüksek düzeyde bağlayıcılığı söz konusudur.

Toplumsal cinsiyet eşitliğinin yasal düzeyde benimsenmesi yönündeki ilk adımların başlangıç noktası 1985 yılına rastlar. Özellikle Avrupa Birliği müktesebatına uyum noktasında yapılacak düzenlemeler konusunda devlet kurumlarını daha yüksek bir motivasyonla harekete geçiren husus AB adaylık sürecinin başlangıcıyla birlikte olmuştur (Eray, 2015, s.125). 1985 yılında kabul edilen Kadınlara Karşı Her Türlü Ayrımcılığın Önlenmesi Sözleşmesi, Türkiye’nin cinsiyet eşitliğini sağlamaya yönelik bir politika ve taahhüt olarak önemli kabul edilir. $\mathrm{Bu}$ bağlamda sürecin gözetiminden sorumlu kılınan Kadının Statüsü ve Sorunları Genel Müdürlüğü 1990 yılında kurulmuştur. 2003 yılındaki AB’nin Cinsiyet Eşitliği Topluluk Programi'na dâhil olmuştur (Koray, 2011, s.35). Böylece İstihdam Stratejisini izleme süreci de başlatılmıştır. Toplumsal Cinsiyet politikaları bağlamında yapılan önemli düzenlemelerden birisi de 2002 yılında kabul edilen Türk Medeni Kanunu'dur. Yeni Medeni Yasa, AB cinsiyet eşitliği politikaları ile uyumlu olmayan hususları dikkate alınarak yürürlüğe konulmuştur. Bu bağlamda bir diğer önemli düzenleme ise İş Kanunu ile olmuştur. İş Kanunu özellikle eşit davranış ve işyerinde cinsel taciz gibi konularda çağdaş normlar düzeyinde düzenlemeler içermektedir. Doğum izni süresinin AB müktesebatı ile uyumlu hale getirilerek doğum öncesi ve sonrasını da kapsayacak şekilde toplam 16 haftaya çıkarılması, istihdam politikalarının toplumsal cinsiyet politikalarını ile bütünlük kazanmasını sağlamıştır. Yasal çerçevede gerçekleştirilen düzenlemelerden birisi de Türk Ceza Kanunu’dur. Ceza Yasası ile cinsel saldırı suçları yeniden düzenlenmiş, aile içi şiddet karşısında alınması gerekli önlemlere yer verilmesi ve toplumsal cinsiyet eşitliği açısından yargı yerlerinin etkin işleyişi adına oluşturulan aile mahkemeleri atılan dikkat çekici adımlar olmuştur (Koray, 2011, s.37). 12 Eylül 2010 yılında yapılan halk oylaması ile değiştirilen 1982 Anayasasının 10/3. Maddesi, toplumsal cinsiyet konusunda Türkiye'nin belki de en önemli gelişmesi olmuştur. Dezavantajlı toplumsal grupların fırsat eşitliğini sadece kâğıt üzerindeki eşitlik karar ve politikaları ile gerçekleşemeyeceğinin anlaşılması, Türkiye'de de bu alanda düzenleme yapılması ihtiyacını doğurmuştur. Geleneksel ve tarihsel bağlamda eşitsizliğin etkisi altındaki bu dezavantajlı grupların firsat eşitliğini elde edebilmelerini sağlamak amacıyla pozitif ayrımcılık ya da $\mathrm{AB}$ terminolojisindeki ifade biçimiyle "olumlu eylem" anayasal bir hüküm ile güvenceye kavuşturulmuştur (Soy, 2017, s.96).

\section{Toplumsal Cinsiyet Eşitliği Politikalarına Yönelik AB İlerleme Raporları}

Avrupa Birliğinin üzerine inşa edildiği ortak değerlerden olan kadın-erkek eşitliği (toplumsal cinsiyet eşitliği), yıllar boyunca $\mathrm{AB}$ gündeminde yer teşkil eden önemli politika alanlarından biri olmuştur. Toplumsal cinsiyet eşitliği konusunda bu güne kadar sürdürülen çalışmaların bu alanda ilerleme sağlanması yönünden katkısı olmakla birlikte, eşitliğin tam anlamıyla gerçekleştirilmesi için daha fazla çaba gösterilmesi gerekliliği AB tarafından dile getirilen bir husustur. Türkiye'de cinsiyet bağlamındaki eşitlikçi politikaların uygulanması konusunda bazı 
ilerlemeler kaydedilmişse de yetersiz kaldığı durumlar da açıkça görülmektedir. Türkiye’de cinsiyet temelli eşitlik anlayışı ve politikalarının büyük ölçüde "modernleşme" ve dünyadaki gelişmelere "ayak uydurma” biçiminde değerlendirilmektedir. Türkiye'de "AB Uyum Süreci” içerisinde düzenlemeler yapılmakla birlikte gerek toplumsal yapının gerekse siyasal iradenin toplumsal cinsiyet eşitliğine mesafeli durması sonucu genel ifadelerin, bazı vaatlerin ötesine pek geçilememiştir. AB ve Türkiye arasındaki ilişkilerde İlerleme raporları aracılığıyla düzenli gözden geçirmelerin başlangıcı 1998 yılıyla birlikte olmuştur. Toplumsal cinsiyet konusunda 1998 İlerleme Raporu’nun 14. sayfasında Türkiye'de kadının statüsü başlıklı bir bölümde ele alınmıştır. Bu raporda Kadınlara Karşı Her Türden Ayrımcılığın Kaldırılması Sözleşmesi’nin onaylanması olumlu bir gelişme olarak belirtilirken, Medeni Kanun, İş Kanunu ve Ceza Kanunu gibi temel yasal metinlerde henüz gerekli uyumlaştırmanın gerçekleşmediği de eleştiri konusu yapılmaktadır. Ayrıca kadınların istihdama katılım oranı ve kadınlardaki okur-yazarlık oranının düşük olması da raporda belirtilen eksikliklerden olmuştur (AB İlerleme Raporu, 1998, s.14).

1999 AB İlerleme Raporunun 13. Sayfasında yine kadının statüsü konusu değinilmiş ve Kadınlara Karşı Her Türden Ayrımcılığın Kaldırılması Sözleşmesi’nde Türkiye’nin bazı maddelere koyduğu çekincelerin Temmuz 1999'da kaldırılması olumlu bir adım olarak değerlendirilmiştir. Raporun 45. Sayfasında yargıda görev alan hâkim savcıların içinde kadınların oranındaki artışın da olumlu görülmektedir (AB İlerleme Raporu, 1999).

2000 yılındaki AB İlerleme Raporu'nun 15. Sayfasında firsat eşitliği başlığıyla ele alınan bölümde, "Doğu Anadolu başta olmak üzere, kızlar için okullaşma oranlarının düşük olması nedeniyle, okur-yazarlık oranı, kadınlar için \%25, erkekler için \%6 civarındadır. Kadınların eğitim durumunu iyileştirmek için daha çok çalışma gereği vardır. Muamele eşitliği açısından, AT müktesebatı ile uygunluk henüz sağlanmamıştır. Medeni Kanun ile ilgili olarak, erkekler ve kadınlar arasında belli ölçüde hukuki ayrımcılık (özellikle aileye ve kadınların çalışma yaşamına ilişkin) devam etmektedir. Mevcut rejim, örneğin, kocanın aile reisi olduğunu ve evlilik birliğini tek başına temsil ettiğini öngörür. Böylece koca, aile reisi olarak, çocukların kanuni velayetine sahip olan taraftır. Kadın STK'larının katkılarıyla, Medeni Kanun'da değişiklikler hazırlanmıştır ve halen parlamentoda müzakere edilmektedir. "Töre cinayetleri” dâhil, aile içinde kadınlara karşı şiddet sorunu, hâlâ ciddi bir kaygı konusudur" ifadelerine yer verilmektedir. Bu bağlamda halen önemli eşitsizliklere vurgu yapılmaktadır. Değerlendirme başlığında da, Mevcut Anayasanın kadın-erkek eşitliği garanti ettiğini, buna rağmen eşit muamele ilkesinin uygulanmasını ve icrasını sağlayabilmek için daha çok çabaya gerek olduğuna, kadınların okur-yazarlık oranlarının yükseltilmesi için ve kadınların kentsel istihdamdaki payını arttırmak için yeni eylemlerin hayata geçirilmesi gerektiğine yönelik önerilerde bulunulmaktadır (AB İlerleme Raporu, 2000, s.36).

2001 AB İlerleme Raporu'nun 28. Sayfasında kadın erkek eşitliği alanında 1982 Anayasası'nın 41. Maddesinin değiştirilerek ailedeki eşler arasında eşitlik ilkesi getirildiği, 66. Maddedeki değişiklik ile eşlerden birisinin yabancı olması durumunda cinsiyete dayalı bir ayrımcılık yapılamaz hale getirildiği, henüz tasarı halindeki Medeni Kanun ile de mevcut ayrımcilıkların 
ortadan kaldırılacağı ve kadın-erkek eşitliğinin pekiştirileceğinin öngörüldüğü ifade edilmektedir. Sosyal Politika ve istihdam başlıklı 13. Bölümde kadın-erkek muamele eşitliği konusunda TBMM'de görüşülen Medeni Kanun ile yaşanan olumsuzlukların giderilebileceği belirtilmektedir. Özellikle “aile reisi” kavramının kaldırılmasının gerekliliğine vurgu yapılmıştır (AB İlerleme Raporu, 2001).

2002 yılındaki İlerleme Raporu'nun 79. Sayfasında çalışma hayatında kadın-erkek arasında eşit muamele ilkesiyle ilişkili sınırlı ilerleme kaydedildiği, İş Kanunu’ndaki değişiklik ile cinsiyete dayalı ayrımcılıkla ilgili ispat yükü konusundaki hükme dikkat çekilmiştir. Ağustos 2002'de kabul edilen iş güvencesi kanunu ile iş sözleşmelerinin, cinsiyet, ırk, medeni hal, ailevi yükümlülükler, hamilelik, din, siyasi görüş, etnik köken ve sosyal sınıf ile ilgili nedenlerden dolayı feshedilemeyeceğine ilişkin bir hüküm önemli bir gelişme olarak dile getirilmiştir. "İşe girme, mesleki eğitim, terfi ve çalışma koşulları bakımından, Türkiye'nin, belli işlere girmede söz konusu olan cinsiyete dayalı mevcut sinırlamaları kaldırması gerekmektedir. Adalet Divanı'nın içtihat hukukundaki yeni gelişmeler de dâhil olmak üzere, ilgili Topluluk mevzuatına uyum için ilave adımlar atılmalıdır. Türkiye'nin hâlâ, yasal ve mesleki sosyal güvenlik programlarına ilişkin Topluluk müktesebatını iç hukuka aktarması gerekmektedir" biçiminde kaleme alınan değerlendirmeler başlığında eksikliklere dikkat çekilmiştir (AB İlerleme Raporu, 2002).

2003 yllı İlerleme Raporunda ilke cinsiyet eşitliği vurgu yer alırken, "namus cinayetleri” konusundaki ceza indirimi uygulamasının sonlandırılması memnuniyetle vurgulanmıştır. Ayrıca evlilik dışı doğran çocuğun "şeref kurtarmak saikiyle” öldürülmesi için ceza artırımına tabi tutulması da olumlu sayılmaktadır. İş Kanunu ile benimsenen her türden ayrımcılığın çalışma hayatında kaldırılmasına yönelik düzenleme de olumlu bulunsa da Avrupa Sosyal Şartı'nın 8. Maddesinin henüz kabul edilmemiş olması eleştirilmektedir. Sosyal koruma alanında bir gelime kaydedilmediği de raporda yer almaktadır (AB İlerleme Raporu, 2003).

2004 yılındaki İlerleme Raporu'nun ekonomik ve sosyal haklar başlıklı bölümünde, "Cinsiyet eşitliği konusunda yapılan çeşitli reformlar, kadın-erkek eşitliği ilkesini güçlendirmiştir. Anayasa'nın 10. maddesi artık kadın ve erkeklerin eşit haklara sahip olduğunu ve devletin görevinin bu eşitliğin uygulamada gerçekleştirilmesini sağlamak olduğunu belirten bir hükmü içermektedir. Yeni Ceza Yasası, kadın hakları açısından genel olarak ilerici hükümleri içermekte ve namus cinayetleri, cinsel saldırı ve bekâret testi gibi suçlarla mücadeleyi öngörmektedir. Ayrımcılık ve aile içi şiddet sorununun çözülmesine yönelik yasal ve pratik çabalara karşın, bu önemli bir sorun oluşturmaya devam etmektedir. Kadınların toplumda eşit bir konuma kavuşmalarının sağlanması için çabaların sürdürülmesi gerekmektedir” ifadesine yer verilmektedir. Yasal düzenlemelerle kaydedilen ilerlemelerin yanı sıra uygulamadaki aksaklıkların altı çizilmiştir (AB İlerleme Raporu, 2004).

2005 İlerleme Raporu'nun Ekonomik ve Sosyal Haklar Bölümünde, bir önceki yılki rapordaki ile benzer şekilde Türk Ceza Kanunu'nda yapılan değişikliğin önemli derece bazı iyileștirmeler sağlamış olmasından söz edilirken, genel olarak kadın hakları konusundaki alınan mesafenin 
yeterli olmadığı da belirtilmektedir. "Endişe verici alanlar" olarak sayılan başlıklar, kadın cinayetleri, aile içi şiddet, namus cinayetleri, yüksek orandaki okuma-yazma bilemeyen kadınların oranı, hem ulusal parlamentoya hem de yerel yönetimlerde kadınların düşük düzeyde temsil edilmesi ile istihdama katılan kadın oranındaki yetersizlik eleştiri konusu yapılmaktadır (AB İlerleme Raporu, 2005).

2006 yılı İlerleme Raporu'nun 59. sayfasında, "Cinsiyet eşitliği ve kadın hakları konusu, Türkiye'de artan bir şekilde kamuoyunun dikkatini çekmektedir. Yasal çerçeve genel olarak tatmin edicidir. Ancak, kadın hakları, özellikle ülkenin fakir bölgelerinde yeterince korunmamaktadır" denilerek konuyla ilgili uygulama yetersizliklerine vurgu yapılmıştır ( $\mathrm{AB}$ İlerleme Raporu, 2006).

2007 İlerleme Raporu, Ailenin Korunması Kanunu yeni değişikliklerle birlikte ailedeki bütün bireylerin korunması güvence altına alınmış olduğunu, töre cinayetleri ve aile içi şiddetle mücadele kapsamında uygulamaya sokulan Başbakanlık Genelgesi ile Kadının Statüsü Genel Müdürlüğü koordinasyonunda kamu kurum ve kuruluşları ve sivil toplum kuruluşlarını da sisteme dâhil ettiği olumlu bir gelişme olarak ifade edilmektedir. Ayrıca ilköğretimde, cinsiyetler arasındaki farkın \%5’ten \%4,6'ya gerilemiş olduğu, iş kurma hakkı kapsamında hemşirelik mesleği için cinsiyet ayrımcılığının ortadan kaldırıldığı olumlu gelişmeler olarak değerlendirilmiştir (AB İlerleme Raporu, 2007).

2008 AB İlerleme Raporu’nun ekonomik ve sosyal hakları bölümünde, kadın haklarıla ilgili olarak töre cinayetleri ve kadınlara yönelik aile içi şiddet ile mücadele kapsamındaki Başbakanlık Genelgesi'nin kamu kurumları arasındaki işbirliğinin geliştirilmesine önemli katkı yaptığı dile getirilmektedir. Adli ve kolluk birimlerinin cinsiyet eşitliği konusunda eğitime alındıklarını ve bu alandaki adımların devam ettirildiğĭ ayrıca sağlık çalışanları açısından da bir cinsiyet duyarlılığı konusunda eğitim programlarının düzenlendiği memnuniyet verici gelişmeler olarak sayılmıştır. Buna rağmen kadın sığınma evlerindeki kapasite artışının çok az gerçekleştiği eleştirisi de yer almıştır. İlköğretimde cinsiyetler arasındaki farkın \%2,3 gibi bir düzeye gerilediği ve bu alandaki dengesizliğin azaldığı belirtilmiştir. Bunların yanında, kadınların istihdama katılımda hala yetersiz bir durumun varlığı dile getirilmiş, mevcut oranların hem $\mathrm{AB}$ hem de OECD ortalamalarının çok altında olduğu da vurgulanmıştır. Kadınların siyasal katılımı ve temsili açısından sorunların varlı̆̆ının devam ettiği belirtilirken, Diyanet İşleri Başkanlığı WEB sayfasında cinsiyet eşitliği noktasında bazı ayrımcı ifadelerin olması eleştirilmiştir. Genel olarak kadın hakları ve cinsiyet eşitliği konusundaki yasal mevzuatın yeterli olduğu ancak, ekonomik hayata katılım, firsat eşitliği, eğitim ve sağlık hizmetlerine erişim ve siyasal yetkiler konularında erkekler ile kadınlar arasındaki dengesizliklerin giderilmesi amacıyla daha fazla çabanın ortaya konulması ve ek önlemlerin alınması gerektiğinin altı çizilmiştir (AB İlerleme Raporu, 2008).

2009 İlerleme Raporu'nda ilk kez toplumsal cinsiyet ifadesinin kullanıldığı görülmektedir. Önceki raporlarda daha çok kadın-erkek eşitliği ve cinsiyet eşitliği gibi kavramlar tercih edilmişti. Bu raporun ekonomik ve sosyal hakları başlıklı bölümünde toplumsal cinsiyet 
konusunda önemli kabul edilen TBMM Kadın Erkek Fırsat Eşitliği Komisyonu’nun kurulmuş olması belirtilmiştir. Bu Komisyon aracıllı̆ıyla toplumsal cinsiyet eşitsizliğine yönelik şikâyet ve başvuruların öncelenecek olması olumlu bir gelişme sayılmıştır. Ancak toplumsal cinsiyet eşitliği konusunda görevli bir kurumun henüz oluşturulmadığı eleştiri konusu edilmektedir. Eleştiriler arasında kadınların siyasal katılım ve temsil düzeylerinin yetersizliği ile işgücüne katılımının düşük olması da yer almaktadır (AB İlerleme Raporu, 2009).

2010 yılı AB İlerleme Raporu, ekonomik ve sosyal haklar başlıklı bölümde toplumsal cinsiyet ve kadın hakları konusunda iyileşmeler sağlandığı belirtilmiştir. Özellikle 12 Eylül 2010 tarihinde yapılan Anayasa Değişikliği ile benimsenen pozitif ayrımcılık düzenlemesinin çok olumlu karşılandığı görülmektedir. Kadınların istihdamı ve fırsat eşitliğinin teşviki amacıyla çıkarılan Başbakanlık Genelgesi de olumlu karşılanmıştır. Bunun yanı sıra toplumsal cinsiyet konusunda Türkiye'nin devam edegelen sorunları olduğu; bunların kadına yönelik aile içi şiddet, kadınların hem siyasal katılım ve temsil hem de üst düzey kamusal görevlere erişim ve temsili açısından yetersizliklere dikkat çekilmiştir (AB İlerleme Raporu, 2010).

2011 İlerleme Raporu, ekonomik ve sosyal haklar bölümünde kadın hakları ve toplumsal cinsiyet konusunda çok az bir ilerleme olduğunu ifade etmiştir. Bu ilerlemeler arasında çalışan ebeveynler için getirilen kolaylıkların kamu görevlilerinin iş ve özel yaşam dengesini olumlu etkileyeceği, işyerlerinde taciz ve psikolojik taciz (mobbing) konusunda mücadeleye yön vermek ve daha üst bir duyarlılık oluşturma açısından yürürlüğe konulan Başbakanlık Genelgesi'nin çok önemli olduğu kaydedilmiştir. Yine kadınların istihdama katılım oranının artış gösterdiği, ilköğretimdeki cinsiyetler arasındaki dengesizliğin yok denecek kadar düşük seviyeye gerilediği de memnuniyet verici gelişmeler olarak sayılmıştır. Ancak, toplumsal cinsiyet alanında, töre ve namus cinayetleri, kadına yönelik aile içi şiddet ile mücadele ve erken yaşta zorla evlilik gibi başlıkların Türkiye açısından önemli sorunlar olarak varlığını sürdürmektedir görüşüne de yer verilmiştir. Son olarak da Toplumsal Cinsiyet Eşitliği Ulusal Eylem Planı'nın uygulamaya geçirilmesi noktasında kapasite eksikliğine vurgu yapılmıștır (AB İlerleme Raporu, 2011).

2012 İlerleme Raporu ile kadın haklarına saygı ve toplumsal cinsiyet eşitliği bağlamında mevzuatta iyileştirmeler yapıldığı, özellikle Ailenin Korunması ve Kadına Karşı Şiddetin Önlenmesine Dair Kanun sayesinde aile bireylerinin şiddete karşı korunmasının amaçlandığı, kamu kurumları ile sivil toplum kuruluşlarının işbirliği olumlu bulunmuştur. Ayrıca 2012-2015 yıllarını kapsayan Kadına Yönelik Şiddetle Mücadele Ulusal Eylem Planı’nın kabul edilerek uygulamaya geçirildiği, plan ile mevzuat, bilinçlendirme, tutum değişikliği, kadınların güçlendirilmesi, önleyici hizmetler, sağlık hizmetleri ve paydaşlar arasındaki işbirliğinin öne çıkarıldı̆̆ 1 ifade edilmiştir. Yine toplumsal cinsiyet konusunda Jandarma Personeline eğitim verilmesine ilişkin faaliyetlerin önemli ve faydalı olduğu dile getirilmiştir. Bununla birlikte kadınların işgücüne, siyasete, daha fazla katılımının gerekli olduğu, erken yaşta ve zorla yaptırılan evliliklerin önemli sorunlar olmaya devam ettiği eleştiriler arasında yer almıştır (AB İlerleme Raporu, 2012). 
2013 AB İlerleme Raporu, 2010 Anayasa Değişikliği ile kabul edilen pozitif ayrımcılık konusundaki kanunların yürürlüğe girmemiş olduğu belirtilmektedir. Kadın hakları ve toplumsal cinsiyet konusundaki mevzuat ve eylem planlarının uygulamalarının devam ettirildiği, ancak mevzuatın siyasal, ekonomik ve sosyal açıdan uygulamaya geçirecek daha fazla çabanın sarf edilmesi gerektiği ifade edilmiştir. Bütün bunlara rağmen toplumsal cinsiyet eşitliği noktasında, eğitim ve iş piyasasına erişim, siyasal katılım ve temsil, kadına yönelik şiddet (namus cinayetleri de içinde) erken yaşta ve zorla yaptırılan evlilikler konularının Türkiye açısından önemli sorunlar olarak varlığını koruduğu vurgulanmıştır. Kadın ve fırsat eşitliği kapsamında kamu ve özel sektörde kadın istihdamını arttırmak amaçlı tedbirler ve teşvik edici çabalara rağmen özellikle kamu bürokrasisinde üst düzey pozisyonlarda kadınların yer alışında beklenen artış yakalanamamıştır. İş ve yaşam dengesini sağlayacak politikalar ile kadınların kariyer çizgileri dikkate alınarak oluşturulması gerektiği, toplumsal kalıp yargıların ortadan kaldırılması noktasında adımlar atılması gerektiği belirtilmiştir. Son olarak da Ayrımcılıkla Mücadele ve Eşitlik Kurumu'nun henüz kurulmadığı da eleştiriler arasındadır (AB İlerleme Raporu, 2013).

2014 AB ilerleme Raporu'nda bir önceki raporda olduğu gibi yine pozitif ayrımcılık konusunda anayasal değişikliği yapılmış olmasına rağmen alt düzeydeki düzenlemelerin hayata geçirilememiş olması nedeniyle eleştiri getirilmektedir. Şiddet uygulayan eşler için önleyici hapis cezası tedbirlerinin yer aldığı Ailenin Korunması ve Kadına Karşı Şiddetin önlenmesine Dair Kanun'un uygulamasındaki etkinlik, şiddetle mücadele konusundaki personelin niteliği ve niceliği ve eğitimine vurgu yapılmaktadır. Şiddetin Önleme Merkezlerinin iki ilde daha pilot uygulama kapsamında faaliyete geçirilmiş olması memnuniyetle karşılanmıştır. Kadınların istihdama katılımında bir artış olsa da henüz yeterli görülmemektedir. Ortaöğretimde toplumsal cinsiyet farklılığının azalmaya devam ettiği, ancak bazı bölgelerde bu eşitsizliğin çok ileri ve rahatsız edici boyutta olduğu bildirilmiştir (AB İlerleme Raporu, 2014).

2015 AB İlerleme Raporu'nda eksiklikler olarak sıralanan maddeler arasında; toplumsal cinsiyet temelinde şiddet, ayrımcılık ve azınlıklara yönelik nefret söylemi, lezbiyen, eşcinsel, biseksüel, transseksüel ve interseks (LGBTI) kişilerin haklarıyla ilgili saygı kaygı duyulan konular olarak sayılmıştır. Özellikle LGBTI bireylerin ve azınlıkların işgücüne katılımıyla ilgili şikâyetlerin sürdüğü belirtilmektedir. Fırsat eşitliği bağlamında kadınların işgücüne katılımıyla ilgili de bir ilerleme sağlanamamıştır. Ayrıca kadın ve erkek arasındaki ücret eşitsizliklerinin devam ettiği eleştirisi getirilmiştir. Erken yaşta evlilik ve çocuk işçiliği nedenleriyle okullardan ayrılanlar yüzünden eğitimde cinsiyet farklılı̆̆ı sorunu çözümlenememiştir (AB İlerleme Raporu, 2015).

2016 AB İlerleme Raporu, Türkiye İnsan Hakları ve Eşitlik Kurumu Kanunu'nun kabul edilmiş olmasını memnuniyet verici bir gelişme olarak görmektedir. Ancak bu kurumun henüz kurulmamış olmasını da önemli bir eksiklik olarak değerlendirmektedir. Geçen yılki rapor ile benzeşen bir şekilde toplumsal cinsiyet temelli şiddet, ayrımcılık, azınlıklara yönelik nefret söylemi, nefret suçu, LGBTI bireylerin temel insan haklarının ihlal edildiği önemli eleştiriler arasında yer almaktadır. "Çalışan anne-babaların kısmi süreli çalışmalarıyla ilgili yasal değişikliğin gerçekleşmiş olduğu, ancak çocukların, yaşlı ve hasta kişilerin bakımına yönelik 
kurumların ve hizmetlerin yetersiz oluşu, bakım konusunda toplumsal cinsiyet önyargıları nedeniyle kadınların işgücüne katılımını engelleyici etkisini sürdürmektedir” denilerek eksikliğe vurgu yapılmıştır (AB İlerleme Raporu, 2016).

2017 yılındaki İlerleme Raporu yayımlanmamış olması nedeniyle 2018 yılı AB İlerleme Raporu incelemeye tabi tutulmuştur. 2018 yllı İlerleme Raporu'nda da özellikle toplumsal cinsiyet temelli şiddet ve ayrımcılığın devam ettiği, nefret suçu, nefret söylemi ve LGBTI bireylerle ilgili ciddi düzeyde temel insan hakkı ihlallerine maruz kaldıkları belirtilmektedir (AB İlerleme Raporu, 2018).

\section{Sonuç ve Değerlendirme}

İnsanlığın en eski farklıllğ̆ olduğu kadar en çok tartışılan ve belki de en çok mücadeleye konu olanı, toplumsal cinsiyettir. Neredeyse bütün dünyada ve tarih boyunca görülen toplumsal cinsiyet sorunu, önce temel insan hakları kapsamında ele alınmış ve kadınların bu alanda hak arayışlarına konu olmuştur. Ancak bu boyutuyla toplumsal cinsiyet konusundaki hak arayışlarında beklenen gelişme ve iyileşme sağlanamamıştır. Sonraki süreçte toplumsal cinsiyet konusu, ülkelerin gelişimi ve kalkınmasında önemli hale gelişi, özellikle kadınların ülkedeki son derece değerli bir beşeri sermaye olarak kabul edilir olması sonrası, kadın-erkek eşitliği konusundaki baş savunucu ve eşitlik arayan aktör olarak devletlerin rol üstlendiği görülmektedir. $A B$ de aynı bakış açısının etkisiyle önce işgücü piyasasındaki rekabet avantajı elde etmenin bir aracı olarak kadın erkek eşitliği ve firsat eşitliği bağlamında karar ve politikalar üretmiş ve bunların önce üye ülkelere daha sonra aday ülkelere benimsetilmesine odaklanmıştır. Başlangıçta kadın ve erkek arasında fırsat eşitliği arayışları olarak kendini gösteren süreçte ikinci aşamada pozitif ayrımcılık uygulamaları devreye girmiştir. Geçmişi çok eskilere dayanan ve kültürel ve sosyal arka planı olan çeşitli önyargı ve kalıp yargıların derinleştirdiği eşitsizliklerin ortadan kaldırılması için ancak bu gruplar için bazı olumlu ayrımclık adımlarının atılması gerekliliği ortaya çıkmış ve benimsenmiştir. Son aşamada ise toplumsal cinsiyet eşitliği konusundaki temel karar ve politikaların anaakımlaştırılması sürecine geçilmiştir. Başka bir ifade ile toplumsal cinsiyet eşitliği politika, karar ve eylemlerinin ülkelerin temel düzenlemeleri için yerleştirilmesine yönelik çabalar öne çıkmıştır.

Türkiye, Avrupa Birliği'ne üyelik sürecine ilişkin Kopenhag kriterlerine uyum hedefiyle gerçekleştirilen yasal ve idari reformlarla demokratikleşme ve kadın hakları bakımından önemli kazanımlar elde etmiştir. Bu kazanımlar Türkiye gibi ataerkil yapının son derece kemikleştiği ülkelerde önemli birer gelişmedir. Avrupa ve Avrupa’nın benimsediği kadın hakları kavramı, Türkiye gibi bir ülke için önemli bir çıkıs noktasıdır. Ama bu, Avrupa'nın toplumsal cinsiyet eşitliğini ana plan ve politikalara yerleştirdiği ve tüm sosyal, kültürel ve politik örgütlenmeleri bu anlayış üzerinden şekillendirdiği anlamına da gelmez. Toplumsal cinsiyet eşitliğinin hayata geçirilmesi var olan tutumların daha doğrusu tutumları besleyen ataerkil zihniyetin değişmesi doğrultusunda hareket edecek iradenin örgütlenmesiyle gerçekleşecektir. Türkiye-AB ilişkileri, 1999 Helsinki Zirvesi ile daha farklı bir evreye girmiştir. Bu süreçle birlikte Türkiye, toplumsal cinsiyet konusunda iç düzenleme ve politikalarını $\mathrm{AB}$ müktesebatı ile uyumlaştırma çabalarına girişmiştir. Çeşitli Anayasal ve yasal düzenlemeler yanında çok sayıdaki ikinci düzeydeki 
düzenlemeler ile eylem planlarını uygulamaya sokmuştur. Ancak gelinen noktada, Türkiye mevzuat olarak ve uygulayıcı kurum ve kuruluşlar yönüyle gerekli adımları atmış olsa da toplumsal cinsiyet eşitliğini ideal noktaya taşımayı başaramamıştır. Özellikle namus ve töre cinayetleri, kadına yönelik aile içi şiddet, LGBTI bireylerine yönelik nefret söylemi ve nefret suçu gibi konularda yeterli ilerlemeyi sağlayamamıştır. Kadınların siyasal katılım ve temsili ile kamu görevlerinde üst pozisyonlarda yeterli derecede temsil edilemeyişi gibi önemli sorunları aşmayı başaramamıştır. AB İlerleme Raporları genelde bu başlıklar ile Türkiye'yi hem attı̆̆ı olumlu adımlar nedeniyle desteklemiş hem de eksiklikler konusunda eleştirmekten geri kalmamıştır. Sonuç olarak toplumsal cinsiyet konusu, Türkiye'nin toplumsal yapısı, kültürel özellikleri gibi nedenlerle kolayca çözüme kavuşturmayacağı sorun alanları olarak varllğını sürdürmektedir. Kısa vadede kolayca çözüme kavuşacak gibi de görünmemektedir.

\section{Kaynakça}

Ateş, N. (2018), Toplumsal cinsiyet bağlamında türk siyasal yaşamında kadının yeri (Yayımlanmamış Yüksek Lisans Tezi), Dumlupınar Üniversitesi Sosyal Bilimler Enstitüsü, Kütahya.

Avrupa Birliği Türkiye İlerleme Raporu (1998).Türkiye’nin katılım yönünde ilerlemesi üzerine Avrupa Komisyonu düzenli raporu, Erişim adresi: https://www.ab.gov.tr/files/AB_Iliskileri/AdaylikSureci/IlerlemeRaporlari/Turkiye_Ilerl eme_Rap_1998.pdf

Avrupa Birliği Türkiye İlerleme Raporu (1999).Türkiye’nin katıllm yönünde ilerlemesi’ne ilişkin Avrupa Komisyonu düzenli raporu, Erişim adresi: https://www.ab.gov.tr/files/AB_Iliskileri/AdaylikSureci/IlerlemeRaporlari/Turkiye_Ilerl eme_Rap_1999.pdf

Avrupa Birliği Türkiye İlerleme Raporu (2000).Türkiye'nin katıllım yönünde ilerlemesi’ne üzerine Avrupa Komisyonu düzenli raporu, Erişim adresi: https://www.ab.gov.tr/files/AB_Iliskileri/AdaylikSureci/IlerlemeRaporlari/Turkiye_Ilerl eme_Rap_2000.pdf

Avrupa Birliği Türkiye İlerleme Raporu (2001).Türkiye’nin Avrupa Birliği’ne katıllm sürecine ilişkin ilerleme raporu, Erişim adresi: https://www.ab.gov.tr/files/AB_Iliskileri/Adaylik Sureci/IlerlemeRaporlari/Turkiye_Ilerleme_Rap_2001.pdf

Avrupa Birliği Türkiye İlerleme Raporu (2002).Türkiye’nin Avrupa Birliği’ne katıllm sürecine ilişkin ilerleme raporu, Erişim adresi: https://www.ab.gov.tr/files/AB_Iliskileri/Adaylik Sureci/IlerlemeRaporlari/Turkiye_Ilerleme_Rap_2002.pdf

Avrupa Birliği Türkiye İlerleme Raporu (2003). Türkiye’nin Avrupa Birliği’ne katıllm sürecine ilişkin ilerleme raporu, Erişim adresi: https://www.ab.gov.tr/files/AB_Iliskileri/Adaylik Sureci/IlerlemeRaporlari/Turkiye_Ilerleme_Rap_2003.pdf

Avrupa Birliği Türkiye İlerleme Raporu (2004).Türkiye’nin katıllm yönünde ilerlemesine ilişkin düzenli raporu, Erişim adresi: https://www.ab.gov.tr/files/AB_Iliskileri/AdaylikSureci/ IlerlemeRaporlari/Turkiye_Ilerleme_Rap_2004.pdf 
Avrupa Birliği Türkiye İlerleme Raporu (2005). Avrupa Komisyonu Türkiye ilerleme raporu, Erişim adresi: https://www.ab.gov.tr/files/AB_Iliskileri/AdaylikSureci/Ilerleme Raporlari/Turkiye_Ilerleme_Rap_2005.pdf

Avrupa Birliği Türkiye İlerleme Raporu (2006). Avrupa Komisyonu Türkiye ilerleme raporu, Erişim adresi: https://www.ab.gov.tr/files/AB_Iliskileri/AdaylikSureci/Ilerleme Raporlari/Turkiye_Ilerleme_Rap_2006.pdf

Avrupa Birliği Türkiye İlerleme Raporu (2007). Avrupa Komisyonu Türkiye ilerleme raporu, Erişim adresi: https://www.ab.gov.tr/files/AB_Iliskileri/AdaylikSureci/Ilerleme Raporlari/turkiye_ilerleme_rap_2007.pdf

Avrupa Birliği Türkiye İlerleme Raporu (2008). Avrupa Komisyonu Türkiye ilerleme raporu, Erişim adresi: https://www.ab.gov.tr/files/AB_Iliskileri/AdaylikSureci/Ilerleme Raporlari/turkiye_ilerleme_rap_2008.pdf

Avrupa Birliği Türkiye İlerleme Raporu (2009). Avrupa Komisyonu Türkiye ilerleme raporu, Erişim adresi: https://www.ab.gov.tr/files/AB_Iliskileri/AdaylikSureci/Ilerleme Raporlari/turkiye_ilerleme_rap_2009.pdf

Avrupa Birliği Türkiye İlerleme Raporu (2010). Avrupa Komisyonu Türkiye ilerleme raporu, Erişim adresi: https://www.ab.gov.tr/files/AB_Iliskileri/AdaylikSureci/Ilerleme Raporlari/turkiye_ilerleme_rap_2010.pdf

Avrupa Birliği Türkiye İlerleme Raporu (2011). Avrupa Komisyonu Türkiye ilerleme raporu, Erişim adresi: https://www.ab.gov.tr/files/AB_Iliskileri/AdaylikSureci/Ilerleme Raporlari/2011_ilerleme_raporu_tr.pdf

Avrupa Birliği Türkiye İlerleme Raporu (2012). Avrupa Komisyonu tarafindan Avrupa Parlamentosu ve Konsey'e sunulan Türkiye ilerleme raporu, Erişim adresi: https://www.ab.gov.tr/files/2012_ilerleme_raporu_tr.pdf

Avrupa Birliği Türkiye İlerleme Raporu (2013). Avrupa Komisyonu tarafindan Avrupa Parlamentosu ve Konsey'e sunulan Türkiye ilerleme raporu, Erişim adresi: https://www.ab.gov.tr/files/2013\%20ilerleme\%20raporu/2013_ilerleme_raporu_tr.pdf

Avrupa Birliği Türkiye İlerleme Raporu (2014). Avrupa Komisyonu tarafindan Avrupa Parlamentosu ve Konseye ve Sosyal ve Ekonomik Komiteye ve Bölgeler Komitesine sunulan Türkiye ilerleme raporu, Erişim adresi: https://www.ab.gov.tr/files/ilerleme RaporlariTR/2014_ilerleme_raporu_tr.pdf

Avrupa Birliği Türkiye İlerleme Raporu (2015). Avrupa Komisyonu tarafindan Avrupa Parlamentosu ve Konseye ve Sosyal ve Ekonomik Komiteye ve Bölgeler Komitesine sunulan Türkiye ilerleme raporu, Erişim adresi: https:/www.ab.gov.tr/files/5\%20Ekim/ 2015_ilerleme_raporu_tr.pdf

Avrupa Birliği Türkiye İlerleme Raporu (2016). Avrupa Komisyonu tarafindan Avrupa Parlamentosu ve Konseye ve Sosyal ve Ekonomik Komiteye ve Bölgeler Komitesine sunulan Türkiye raporu, Erişim adresi: https://www.ab.gov.tr/files/pub/2016_ ilerleme_raporu_tr.pdf 
Avrupa Birliği Türkiye İlerleme Raporu (2018). Avrupa Komisyonu tarafindan Avrupa Parlamentosu ve Konseye ve Sosyal ve Ekonomik Komiteye ve Bölgeler Komitesine sunulan Türkiye raporu, Erişim adresi: https://www.ab.gov.tr/siteimages/pub/ komisyon_ulke_raporlari/2018_turkiye_raporu_tr.pdf

Ayata, A. (2009). Türkiye usulü Avrupa Birliğine yakınlaşma, Akademik Araştırmalar Dergisi, $40,32-43$.

Çifçi, S. (2018). 20-65 yaş arası kişilerin toplumsal cinsiyet algısı ve etkileyen faktörler Mardin örneği (Yayımlanmamış Doktora Tezi), Dicle Üniversitesi Sağlık Bilimleri Enstitüsü, Diyarbakır.

Eray, Ş. (2015). Yeni kurumsalcı yaklaşımlar çerçevesinde Türkiye'de toplumsal cinsiyet eşitliği kamu politikası: eğitim ve siyasal katılım alt politika örnekleri (Yayımlanmamış Doktora Tezi), Gazi Üniversitesi Sosyal Bilimler Enstitüsü, Ankara.

Göçmener, S. (2008). Avrupa Birliği'ne uyum sürecinde Türkiye'de kadın-erkek eşitliği (Yayımlanmamış Yüksek Lisans Tezi), Bahçeşehir Üniversitesi Sosyal Bilimler Enstitüsü, İstanbul.

Gülel, D. (2012). A comparative study to show resemblances in gender policies of the EU member states that derive from acquis communautaire obligations and to reflect their differences which arise from diversified political and socio-economic conditions (Yayımlanmamış Yüksek Lisans Tezi), Akdeniz Üniversitesi Sosyal Bilimler Enstitüsü, Antalya.

Günay, G., Bener, Ö. (2011). Kadınların toplumsal cinsiyet rolleri çerçevesinde aile içi yaşamı algılama biçimleri, TSA, 15(3), 157-171.

Karasar, N. (2005). Bilimsel Araştırma ve Yöntemi (15. Baskı), Ankara: Nobel.

Koray, M. (2011). Avrupa Birliği ve Türkiye’de “Cinsiyet” eşitliği politikaları: Sol feminist bir eleştiri, Çalışma ve Toplum, 2, 1-42.

Pehlivan, P. V. (2017). Toplumsal cinsiyet bağlamında kuramsal yaklaşımlar: Bir literatür incelemesi, İstanbul Ticaret Üniversitesi Sosyal Bilimler Dergisi, 16(31), 497-521.

Saraç, S. (2013). Toplumsal cinsiyet, içinde toplumsal cinsiyet ve yansımaları, Ankara: Atılım Üniversitesi.

Soy, H. (2017). Toplumsal cinsiyet: kadının toplumsal ve hukuki konumu (Yayımlanmamış Yüksek Lisans Tezi), Selçuk Üniversitesi Sosyal Bilimler Enstitüsü, Konya.

Tatlıer Baş, M. M. (2011). Avrupa Birliği’nde toplumsal cinsiyet eşitliğinin ana plan ve politikalara yerleştirilmesi: Hollanda, Romanya ve Türkiye örneklerinin irdelenmesi (Yayımlanmamış Uzmanlık Tezi), T.C Başbakanlık Kadının Statüsü Genel Müdürlügüü, Ankara.

Yücel, G. (2016). Avrupa Birliği eğitim ve kültür politikaları, (Ed. Ali Ayata ve Murat Ercan), İçinde: Avrupa Birliği ve Türkiye ile ilişkileri-ilişkilerin siyasi, askeri, ekonomik ve kültürel çerçevesi, s. 111-130, 2. Baskı, Ankara: Nobel. 